OPEN ACCESS

Edited by:

Amelia Evoli,

Catholic University of the Sacred

Heart, Italy

Reviewed by:

Ernestina Santos,

University Hospital Center of

Porto, Portugal

Matteo Garibaldi,

Sapienza University of Rome, Italy

*Correspondence:

Yi Zhao

zy85070@xwhosp.org

Specialty section:

This article was submitted to

Neuromuscular Diseases,

a section of the journal

Frontiers in Neurology

Received: 23 March 2020

Accepted: 20 July 2020

Published: 02 September 2020

Citation:

Li X, Zhao Y, Liao QJ and Da YW (2020) Myasthenia Gravis Coexisting

With Primary Sjögren's Syndrome:

Report of Three Cases and Literature

Review. Front. Neurol. 11:939

doi: 10.3389/fneur.2020.00939

\section{Myasthenia Gravis Coexisting With Primary Sjögren's Syndrome: Report of Three Cases and Literature Review}

\author{
Xia $\mathrm{Li}^{1}$, Yi Zhao ${ }^{1 *}$, Qiuju Liao ${ }^{1}$ and Yuwei $\mathrm{Da}^{2}$ \\ ${ }^{1}$ Department of Rheumatology \& Allergy, Xuanwu Hospital, Capital Medical University, Beijing, China, ${ }^{2}$ Department of \\ Neurology, Xuanwu Hospital, Capital Medical University, Beijing, China
}

Objective: The coexistence of myasthenia gravis (MG) and primary Sjögren's syndrome (pSS) is rarely reported. This study aims to describe the clinical features, treatment and outcome of MG coexisting with pSS.

Materials and Methods: Herein we reported three cases with the two coexisting diseases, and also searched the PubMed, Medline databases, and China Wanfang databases for the relevant case reports written in English, Chinese, or Japanese with detailed data.

Results: We reviewed a total of 17 patients with both diseases. Fifteen patients were female. The median age at onset was 48 years (range 28-78 years). MG was the initial disease in nine of 17 cases. The median interval between the onsets of the two diseases was 30 months (range 7 months to 20 years). The symptoms of MG included fatigable ptosis (64.7\%), bulbar symptoms (58.8\%), muscle fatigability (64.7\%), diplopia (64.7\%), dyspnea (23.5\%), and facial paralysis (5.9\%). Anti-acetylcholine receptor antibody was positive in $70.6 \%$ patients. All the patients had sicca symptoms. Manifestations of pSS also included swollen exocrine glands (23.5\%), joint pain (23.5\%), hair loss (11.8\%), leukopenia (11.8\%), recurrent oral ulcers (5.9\%), Raynaud phenomenon (5.9\%), and fever (5.9\%). ANA positivity was present in $70.6 \%$ patients, anti-SSA positivity in $47.1 \%$, and double positivity of anti-SSA and anti-SSB in 17.6\%. There were 12 patients (70.6\%) with two autoimmune diseases (pSS and MG), and five patients with more than two autoimmune diseases. Cholinesterase inhibitors were the most commonly prescribed drugs (82.4\%). Seven patients received thymectomy and one patient improved after the operation. Two patients were given intravenous methylprednisolone pulse therapy, and four patients oral steroids combined with immunosuppressants initially. Intravenous immunoglobulin and plasma exchange were used in two patients, respectively, for the respiratory failure. All the patients improved following treatment except one patient who died of MG crisis due to medication withdrawal.

Conclusion: The coexistence of SS with MG is quite rare. The onset of MG may occur before or after the diagnosis of SS. Co-morbidity with MG does not seem to adversely affect the course of SS. Thus, controlling the progress of MG is the critical aspect of treatment.

Keywords: myasthenia gravis, primary Sjögren's syndrome, autoimmune diseases, coexistence, outcome 


\section{INTRODUCTION}

Myasthenia gravis (MG) is a chronic autoimmune neuromuscular disease in which antibodies bind to acetylcholine receptors or to functionally related molecules in the postsynaptic membrane and cause weakness in the skeletal muscles resulting in difficulty in respiration and swallowing, diplopia, and ptosis (1). The weakness typically worsens with exercise and sustained muscle use and fluctuates over the course of a day. A few papers have noted that MG can be accompanied by concomitant autoimmune diseases (ADs), including thyroiditis, chronic inflammatory demyelinating polyradiculoneuropathy, neuromyelitis optica spectrum disease (NMOSD), and connective tissue diseases (CTD) (2). Among the CTDs, systemic lupus erythematosus (SLE) and rheumatoid arthritis (RA) are the most frequently mentioned (1). However, the association of MG with primary Sjögren's syndrome (SS) is unusual.

SS is a common multisystem autoimmune disease characterized by lymphocytic infiltration of exocrine glands. Patients often present with dry mouth and dry eyes due to hypofunction of salivary and lacrimal glands (3). It shows a female predominance of 9:1 and a peak incidence at the age of $\sim 50$ years (4). SS may occur in isolation or coexist with organ-specific autoimmune diseases (called as primary SS, pSS), such as thyroiditis and NMOSD (5). It also can be secondary to other systemic ADs, such as RA, SLE, or systemic sclerosis (SSc) (4). The nervous system is one of the targets of systemic damage in pSS patients (6). Neurologic manifestations of pSS are diverse, and may involve the peripheral nervous system and/or central nervous system (7). The coexistence of MG and pSS is limited to reports of one to two cases (8-21). Herein we report three cases of MG with pSS diagnosed at our hospital and review the relevant literature.

\section{MATERIALS AND METHODS}

\section{Case Presentation Case 1}

A 32-years-old Chinese woman presented with a 3-years history of bilateral fatigable ptosis and dysarthria and 1-year diplopia. She was admitted to the Department of Neurology of our hospital on June 12th, 2019, because of aggravation of her symptoms. She did not have difficulty in swallowing, shortness of breath, or muscle fatigability. The personal and family history was unremarkable. She had a positive response to the neostigmine test and the serum level of anti-acetylcholine receptor (AchR) antibody was $>20 \mathrm{nmol} / \mathrm{L}$ (normal range $0-0.4 \mathrm{nmol} / \mathrm{L}$ ). Computed tomography (CT) scan of the chest revealed a thymic remnant in the anterior mediastinum. She was diagnosed with MG according to definitions of MG (22). Meanwhile, the serum immunological examination was done routinely in order to screen for possible coexisting ADs. Surprisingly, the result of anti-nuclear antibody (ANA) spectrum showed that ANA was positive, with a titer of 1:3,200 and speckled pattern, and antiSSA positive $(++)$. Then the patient was transferred to our department to identify the rheumatic diseases. With regard to her illness history, the patient had suffered from dry mouth and dry eyes for half a year. Her dry mouth did not affect solid food intake. She denied having a rash, photosensitivity, oral ulcers, joint pain or Raynaud phenomenon. Blood routine tests showed a moderate leukopenia (white blood cells $2.59 \times$ $10^{9} / \mathrm{L}$ ). Urinary analysis was normal. Liver, renal functions and levels of creatine kinase (CK) were within normal range. Thyroid function normal. Erythrocyte sedimentation rate (ESR) and C reactive protein (CRP) normal. Immunoglobulin (Ig) G slightly high (17 g/L) and complements slightly low (C3 $0.64 \mathrm{~g} / \mathrm{L}, \mathrm{C} 4$ $0.14 \mathrm{~g} / \mathrm{L}$ ). Other autoantibodies including rheumatoid factor (RF), anti-cyclic citrullinated peptide (CCP) antibody, anticardiolipin antibody, anti-neutrophil cytoplasmic antibodies, the myositis-associated autoantibodies (MAA), and myositis-specific autoantibodies (MSA) including 16 different antigens (Mi-2 $\alpha$, Mi-2 $\beta$, TIF1 $\gamma$, MDA5, NXP2, SAE1, Ku, PMScl100, PM-Scl75, Jo-1, SRP, PL-7, PL-12, EJ, OJ, Ro-52) were all negative. The antithyroid peroxidase (TPO) antibody and anti-thyroglobulin (TG) antibody were also negative. Oral unstimulated salivary flow rate was $0.8 \mathrm{ml} / \mathrm{min}$. Tests for dry eyes done by an ophthalmologist showed tear film break-up time (BUT) of left/right eye was 3.44/10.77 s, respectively; Schirmer test: left $2 \mathrm{~mm} / 5 \mathrm{~min}$, right 3 $\mathrm{mm} / 5 \mathrm{~min}$; Corneal fluorescence staining (-). Biopsy of the labial gland revealed focal lymphocytic sialadenitis with a focus score $\geq 1$. Eventually, the patient was diagnosed with MG and pSS. She was given pyridostigmine bromide $60 \mathrm{mg}$ three times per day, prednisone $30 \mathrm{mg}$ per day, tacrolimus $1 \mathrm{mg}$ twice per day. In a follow-up of 8 months, her symptoms improved obviously.

\section{Case 2}

A 55-years-old Chinese woman was admitted to our department due to dry mouth and dry eyes on October 11th, 2019. She suffered from dry mouth for 1 year but without decay of teeth or swelling of parotid glands. Two months before her admission, she began to have dry eyes and asymmetrical fatiguable ptosis. She also developed diplopia, dizziness and proximal muscle fatigability of lower limbs. She was identified as an asymptomatic hepatitis B virus carrier for 8 years. On admission, physical examination showed bilateral ptosis, more serious on the right side. Bilateral limitation of eye movement. No oral saliva pool. Muscle strength of proximal muscles of lower limbs was grade IV.

She was given a comprehensive laboratory examination involving blood cells, acute phase response markers, serum biochemistry, $\mathrm{CK}$, immunoglobulins, autoantibodies, and hepatitis B virus markers. The clinically significant results showed as follows: hepatitis B surface antigen (HBsAg), hepatitis $B$ e antibody (anti-HBe), and hepatitis B core antibody (anti$\mathrm{HBc}$ ) positive. The levels of $\mathrm{CK}$ was normal. RF was $76 \mathrm{IU} / \mathrm{ml}$. The level of anti-TPO antibody was $78.6 \mathrm{IU} / \mathrm{ml}(0-9)$, anti-TG antibody $10.6 \mathrm{IU} / \mathrm{ml}(0-4)$, but thyroid function normal. The MAA and MSA were all negative. ANA was positive with a titer of 1:320 (homogeneous pattern). Ig G/A/M, complement C3/C4, ESR, and CRP were all normal.

She had a positive response to the neostigmine test and the serum level of anti-AchR antibody was $20 \mathrm{nmol} / \mathrm{L}$. Thyroid ultrasound revealed a diffusely uneven echo pattern and a 0.8 $\times 0.4 \mathrm{~cm}$ hypoechoic nodule in the left lobe. Contrast-enhanced 
chest CT detected an anterior mediastinal mass indicating a thymoma (Figure 1). Oral unstimulated salivary flow rate was $0 \mathrm{ml} / \mathrm{min}$. The presence of dry eyes was confirmed based on the ophthalmic examination. Biopsy of the labial gland revealed focal lymphocytic sialadenitis with a focus score $\geq 1$. As a result, she was diagnosed with pSS, MG and Hashimoto's thyroiditis (HT). Thymectomy was performed and the postoperative pathology indicated Type B1 thymoma according to World Health Organization (WHO) classification (Figure 1). She was given pyridostigmine bromide $60 \mathrm{mg}$ three times per day. In a follow-up of 6 months, her sicca and myasthenia symptoms were relieved.

\section{Case 3}

A 47-years-old Chinese woman was admitted to our department on November 7th, 2019. She suffered from dry mouth and dry eyes for 2 years. She also had hair loss, pain in knee and proximal interphalangeal joints without swelling. She developed fatigue and proximal muscle fatigability of lower limbs 1 year ago and diplopia 5 months ago. One month before admission, she began to have dysarthria, dysphagia, fatigability in chewing and facial paralysis. She had a 3-years history of Hashimoto's thyroiditis and hypothyroidism, and euthyrox was administered. Physical examination showed muscle strength of proximal muscles of lower limbs was grade IV. Laboratory tests showed as follows: white blood cells $(\mathrm{WBC}) 3.49 \times 10^{9} / \mathrm{L}, \operatorname{IgG} 25.6 \mathrm{~g} / \mathrm{L}, \mathrm{ESR}$ $30 \mathrm{~mm} / \mathrm{h}$, and CRP normal. RF was $21 \mathrm{IU} / \mathrm{ml}$ and anti-CCP antibody $104.07 \mathrm{U} / \mathrm{ml}$. Thyroid function was normal, but the level of anti-TPO antibody was $10.4 \mathrm{IU} / \mathrm{ml}$ (0-9), anti-TG antibody negative. Serum level of anti-AchR antibody was 43.89 $\mathrm{nmol} / \mathrm{L}$. The levels of CK was normal. The MAA and MSA were all negative. ANA was 1:320 (+) (speckled pattern), anti-SSA $(+++)$. Oral unstimulated salivary flow rate was $2.4 \mathrm{ml} / \mathrm{min}$ and dry eyes were confirmed by an ophthalmologist. Biopsy of the labial gland revealed focal lymphocytic sialadenitis with a focus score $\geq 1$. Chest CT detected no thymus abnormalities.

The patient was diagnosed with pSS, MG, and HT. She was given pyridostigmine bromide $60 \mathrm{mg}$ three times per day, prednisone $30 \mathrm{mg}$ per day, and tacrolimus $3 \mathrm{mg}$ per day. Her muscle fatigability, dysphonia and dysphagia soon alleviated. But 2 months later, she developed dyspnea when prednisone was tapered to $25 \mathrm{mg}$ per day. Then intravenous immunoglobulin (IVIG) $20 \mathrm{~g}$ per day was administered for 5 days. Her dyspnea was relieved soon. Followed up for 3 months, her condition was stable.

\section{METHODS}

All analyses were based on a review of medical records that had been obtained for clinical purposes or for previous published studies, thus ethical approval was waived. To describe the clinical features, treatment regimens and outcome about patients with pSS and MG, we searched the PubMed, Medline databases and China Wanfang databases for reports of cases by using the keywords "Sjögren's syndrome," "sicca syndrome," "autoimmune diseases," and "myasthenia gravis" in different combinations. Twenty-one cases with the two coexisting diseases were identified in total, and we reviewed the 14 cases written in English, Chinese,

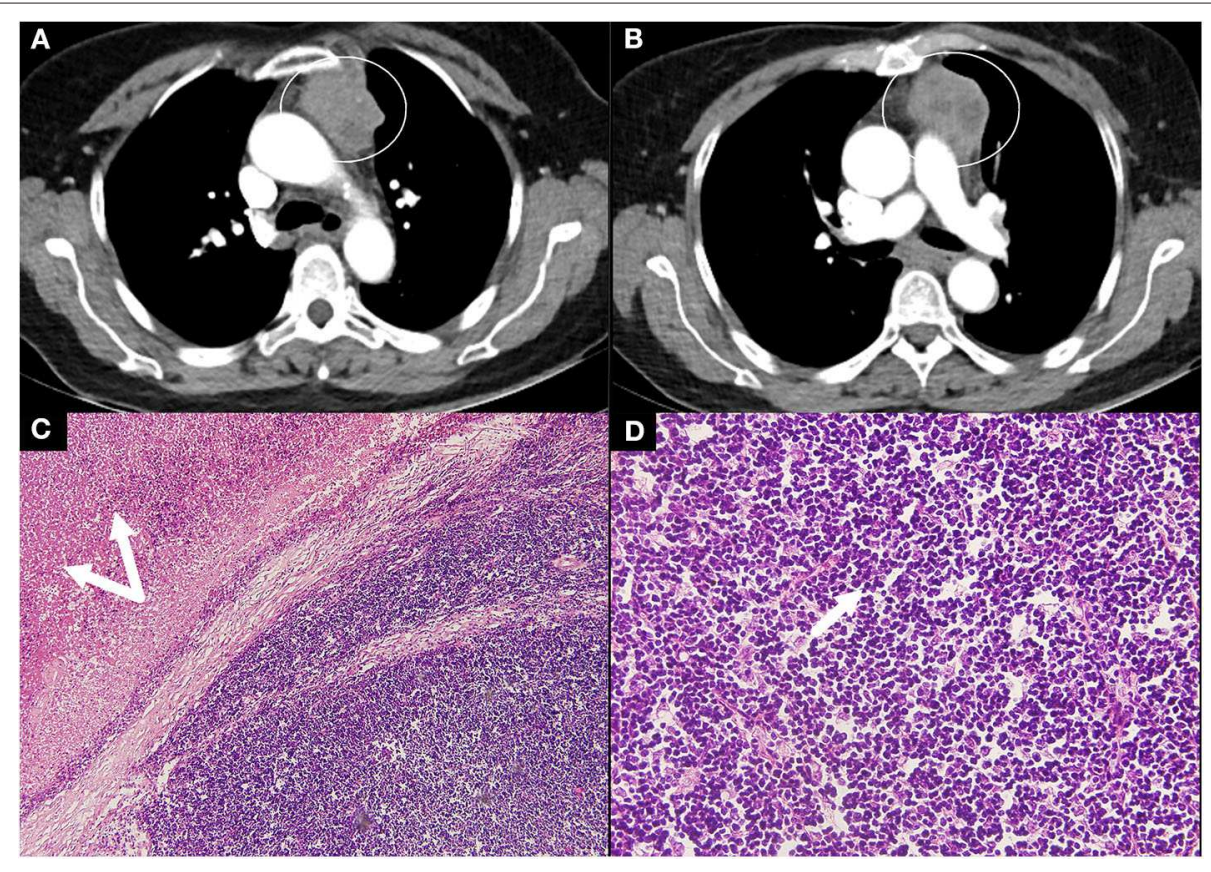

FIGURE 1 | Contrast CT scan and thymoma pathology in case 2. (A,B) Contrast CT scan of the chest showed a large rounded mass (circle) with multiple low-density areas reflecting necrosis. (C,D) Pathology revealed type B1 thymoma according to the WHO classification with massive necrosis (double arrows, magnification, H\&E $\times 10$ ) and a predominance of lymphocytes (arrow, magnification, H\&E ×40). CT, computed tomography; WHO, World Health Organization; H\&E, hematoxylin and eosin. 
or Japanese with detailed data. The clinical features of MG patients with pSS were analyzed with descriptive statistics.

\section{RESULTS}

Through a comprehensive search of literature, we finally identified 14 other cases with MG and pSS (8-21). The details of the 17 patients (including three cases in the present study) are listed in Table 1.

The demographic features, precedence of disease development, common manifestations, autoimmune complications, treatment regimens, and outcome of all 17 patients are reviewed in Table 2. Notably, anti-AcR antibody were positive in 12 out of 17 cases (unclear in the other five patients). Most patients (16 out of 17 cases) were classified as generalized MG presenting with limb muscle fatigability or bulbar symptoms while only one patient was ocular MG. Of seven patients who underwent thymectomy, five had pathologic results: three had thymoma (two with type B1, one with type A according to the WHO classification), and two thymic hyperplasia. Additionally, there were six patients who had lip biopsy and all the results revealed focal lymphocytic infiltration. Interestingly, there were five patients having more than two ADs besides MG and pSS. With regard to treatment, thymectomy relieved the symptoms obviously in the patient with thymoma. Cholinesterase inhibitors were the most commonly used drugs, and three patients were treated efficiently with the drug alone. Other therapeutic methods, including intravenous methylprednisolone pulse, oral steroids, immunosuppressants, plasma exchange (PLEX), and IVIG were also used. Overall, all the patients improved following the treatment except one patient who died of MG crisis due to medication withdrawal by herself.

\section{DISCUSSION}

MG is a B-cell mediated organ-specific autoimmune disease with antibodies against the acetylcholine receptor, muscle-specific kinase (MUSK), lipoprotein-related protein 4 (LRP4), or agrin in the post-synaptic membrane at the neuromuscular junction (23). About $10 \%$ MG patients may have a thymoma, and conversely, one third of patients with thymoma can develop MG (1). Similarly, pSS is also a B-cell mediated systemic autoimmune disease with multiple antibodies including ANA, anti-SSA (Ro) antibody and anti-SSB (La) antibody. Thereafter, there might be a similar immunologic mechanism involving different targets shared by these two diseases. The overall prevalence of neurologic involvement in pSS is $\sim 20 \%$ (24). The neurologic manifestations include peripheral neuropathy, aseptic meningitis, NMOSD, and multiple sclerosis-like manifestations. But the coexistence of pSS and $M G$ is really rare and limited to case reports.

Herein we present three cases of MG coexisting with pSS and offer a review based on the published literature. We notice that MG has rarely been reported to coexist with pSS. But its incidence may have been underestimated, because the sicca symptoms are easily overlooked by a neurologist. The coexistence of MG and pSS show a female predominance and a median age of 48 years at onset, which are consistent with the features of pSS and the age of early onset MG (EOMG). MG occurred before pSS in more than half of the patients. Thus, it is of great importance for a neurologist to screen patients with MG for the presence of other autoimmune rheumatic disorders including pSS.

The frequency of coexistence with other ADs in MG patients has been reported between 11.6 and 32\% (2). Data from a large population-based survey showed that 214 ADs were diagnosed in 185 of $984 \mathrm{MG}$ patients (18.8\%). And 26 of these subjects had two or more ADs (25). Autoimmune thyroid diseases (AITD) is the most common coexisting condition, followed by SLE and RA. Other autoimmune disorders including chronic inflammatory demyelinating polyradiculoneuropathy and NMOSD were also reported. Furthermore, inflammatory myopathy is another rare $\mathrm{AD}$ which can coexist with MG. Garibaldi et al. observed that 13 out of $441(2.9 \%)$ MG patients developed myositis and $10 / 13$ patients occurred simultaneously (26). So the authors recommended myositis should be considered when MG patients had the features of elevated serum CK levels or stable muscle weakness unresponsive to acetylcholinesterase inhibitors (26), in particular for MG patients with thymoma (27). As for the three patients we reported, they all had normal serum CK levels and responded well to the acetylcholinesterase inhibitors. As a result, myositis was ruled out.

Actually, the term "polyautoimmunity" has been used for decades and defined as the presence of two or more ADs in an individual. In this paper, there are 12 patients (70.6\%) having two $\mathrm{ADs}$ (pSS and MG), and five patients having more than two ADs. Moreover, one patient suffered from four ADs simultaneously. On the other hand, pSS often occurs with organ-specific ADs and the most common coexisting AD is also AITD (28). The prevalence of AITD was $11.1-15.7 \%$ in patients with pSS $(29,30)$. Moreover, a study by Lazarus reported that $7.9 \%$ of patients with pSS had two or more ADs (31).

Since the coexistence of MG and pSS is quite rare, the pathogenesis remains elusive. Berrih-Aknin summarized the common mechanisms between MG and SS (32). The frequency of human leukocyte antigen (HLA)-DR3 in the whole group of MG patients was increased compared with the control population, and the same HLA haplotype was one of the loci for susceptibility for SS. The EOMG patients were predominantly women (female to male 9:1) with thymic hyperplasia, including the development of ectopic germinal centers in the thymus and high levels of antiAChR antibody. Sex hormones which may affect both innate and adaptive immune systems are mainly thought to be responsible for this bias. And the formation of ectopic germinal centers in salivary glands was also commonly found in SS patients (32). Serum levels of both B cell activating factor (BAFF) and a proliferation-inducing ligand (APRIL) increased in SS and MG patients (32). In addition, increased expression of interleukin-17 was found in the sera and the thymus of anti-AcR positive MG patients as well as in the saliva of SS (32). These findings highlight the key role of the target organ in the initiation and development of the disease.

It is noticed that although all 17 pSS patients with MG presented with sicca symptoms, no one developed severe systemic damage as far as pSS is concerned (four patients with 
TABLE 1 | Review of present and previous reported cases with MG and pSS.

\begin{tabular}{|c|c|c|c|c|c|c|}
\hline Country & Sex/age & MG features & pSS features & Laboratory tests & Treatment & Outcome \\
\hline $\begin{array}{l}\text { 1966, } \\
\text { United Kingdom } \\
\text { (8) }\end{array}$ & $F / 51$ & $\begin{array}{l}\text { Diplopia, dysphagia, muscle fatigability and } \\
\text { dyspnea for } 23 \text { years; anti-AcR NA }\end{array}$ & $\begin{array}{l}\text { Joint pain for } 3 \text { years, dry mouth for } 3 \text { months; } \\
\text { Raynaud's phenomenon; keratoconjunctivitis } \\
\text { sicca(+); }\end{array}$ & ESR elevated; ANA(+) & $\begin{array}{l}\text { Cholinesterase inhibitor; } \\
\text { thymectomy; analgesics }\end{array}$ & Improved \\
\hline $\begin{array}{l}\text { 1973, Japan } \\
\text { (9) }\end{array}$ & $M / 53$ & $\begin{array}{l}\text { Dysphagia, muscle fatigability, and ptosis for } 13 \\
\text { years; neostigmine test(+); anti-AcR NA; } \\
\text { RNS(+); CT: thymic hypertrophy }\end{array}$ & $\begin{array}{l}\text { Dry mouth for } 1 \text { year; Schirmer(+); salivary flow } \\
\text { rate decreased; Sialography (+); Lip biopsy(+) }\end{array}$ & $\begin{array}{l}\gamma \text {-globulin elevated; ESR } \\
\text { normal, CRP elevated; } \\
\text { RF(+); ANA(-); anti-SMA(+) }\end{array}$ & Cholinesterase inhibitor & Improved \\
\hline $\begin{array}{l}\text { 1973, } \\
\text { Scotland (10) }\end{array}$ & $F / 66$ & $\begin{array}{l}\text { Ptosis, diplopia and generalized muscle } \\
\text { weakness for } 3 \text { years; neostigmine test(+); } \\
\text { anti-AcR NA }\end{array}$ & $\begin{array}{l}\text { Left parotid gland enlargement, dry eyes for } 2 \\
\text { years; Sialography (+); keratoconjunctivitis(+); }\end{array}$ & $\mathrm{RF}(+) ; \mathrm{ANA}(+)$ & Cholinesterase inhibitor & Improved \\
\hline $\begin{array}{l}\text { 1990, } \\
\text { Sweden (11) }\end{array}$ & $F / 40$ & $\begin{array}{l}\text { Muscle fatigability, dysarthria for } 9 \text { months; } \\
\text { anti-AcR(+); tensilon test(+) }\end{array}$ & $\begin{array}{l}\text { Transient dry mouth and a swelling below the } \\
\text { mandible appeared after pyridostigmine } \\
\text { bromide treatment; Schirmer normal; FL(+); } \\
\text { salivary flow rate } 1.8 \mathrm{ml} / \mathrm{min} \text {; Lip biopsy(+) }\end{array}$ & $\begin{array}{l}\text { WBC decreased; ESR } \\
\text { elevated; RF(+); ANA(-) }\end{array}$ & $\begin{array}{l}\text { Pyridostigmine bromide; } \\
\text { thymectomy (thymic } \\
\text { hyperplasia) }\end{array}$ & $\begin{array}{l}\text { Improved; } \\
\text { recurrent swollen } \\
\text { exocrine glands }\end{array}$ \\
\hline $\begin{array}{l}\text { 1999, Japan } \\
\text { (12) }\end{array}$ & $F / 28$ & $\begin{array}{l}\text { Exhaustion, ptosis and diplopia for } 2.5 \text { years; } \\
\text { severe muscle fatigability and dyspnea for } 1 \\
\text { year; anti-AcR (+); tensilon test(+); No thymic } \\
\text { tumors }\end{array}$ & $\begin{array}{l}\text { Sicca symptoms for } 3 \text { years; Swelling of } \\
\text { bilateral parotid glands; Schirmer(+); salivary } \\
\text { flow rate } 0.5 \mathrm{ml} / \mathrm{min} \text {; Sialography (+) }\end{array}$ & ANA, anti-SSA, anti-SSB(+) & $\begin{array}{l}\text { Steroid pulse therapy; Pred } \\
2 \mathrm{mg} / \mathrm{kg} \text { daily; } \\
\text { pyridostigmine bromide; } 5 \\
\text { plasma exchanges }\end{array}$ & Improved \\
\hline $\begin{array}{l}\text { 2003, China } \\
\text { (13) }\end{array}$ & $\mathrm{F} / 48$ & $\begin{array}{l}\text { Muscle fatigability for } 8 \text { years; ptosis, mild } \\
\text { diplopia and fatigue for } 3 \text { years; anti-AcR } \\
\text { elevated; RNS(+) }\end{array}$ & $\begin{array}{l}\text { Dry mouth, dry eyes, dental caries for } 3 \text { years; } \\
\text { Schirmer }(+) ; F L(+) \text {; salivary flow rate } 0.5 \\
\mathrm{ml} / \mathrm{min}\end{array}$ & $\begin{array}{l}\text { ESR } 23 \mathrm{~mm} / \mathrm{h} ; \text { CRP } 1.61 \\
\mathrm{mg} / \mathrm{dl} \text {; anti-SSA, anti-SSB } \\
(-)\end{array}$ & Cholinesterase inhibitor & Improved \\
\hline $\begin{array}{l}\text { 2004, Japan } \\
(14)\end{array}$ & $F / 36$ & $\begin{array}{l}\text { Nausea, cough and high fever; chest CT: } \\
\text { thymoma; } 2 \text { months post-thymectomy, bilateral } \\
\text { ptosis, dysphagia and generalized fatigability } \\
\text { developed; anti-AcR(+); tensilon test(+); } \\
\text { RNS(+) }\end{array}$ & $\begin{array}{l}\text { Dry mouth and dry eyes developed } 1 \text { month } \\
\text { before surgery; Schirmer }(+) \text {; salivary flow rate } \\
0.15 \mathrm{~g} / 2 \mathrm{~min} \text {; lip biopsy }(+) \text {; } 11 \text { months after } \\
\text { surgery, PRCA occurred }\end{array}$ & $\begin{array}{l}\gamma \text {-globulin elevated; ANA } \\
(+) \text {; anti-SSA, anti-SSB (-); }\end{array}$ & $\begin{array}{l}\text { Thymectomy(type-B1 } \\
\text { thymoma); local } \\
\text { radiotherapy; prednisolone; } \\
\text { PRCA: cyclosporin }\end{array}$ & Improved \\
\hline $\begin{array}{l}\text { 2006, China } \\
\text { (15) }\end{array}$ & $F / 28$ & $\begin{array}{l}\text { Dysphagia for } 1 \text { year; fatigable ptosis for } 3 \\
\text { weeks; neostigmine test(+); anti-AcR NA; } \\
\text { fatigue test(+); RNS(+) }\end{array}$ & Dry mouth for 2 years; Schirmer (+) & $\begin{array}{l}\text { RF (+); ANA: NA; anti-SSA } \\
(+)\end{array}$ & Pred $1 \mathrm{mg} / \mathrm{Kg} / \mathrm{d}$ & Improved \\
\hline $\begin{array}{l}\text { 2006, China } \\
\text { (16) }\end{array}$ & $F / 71$ & $\begin{array}{l}\text { Muscle fatigability and mild diplopia for } 4 \text { years; } \\
\text { neostigmine test(+); anti-AcR NA; fatigue } \\
\text { test(+); RNS(+); pyridostigmine bromide } 60 \mathrm{mg} \\
\text { tid, improved; } 3 \text { days of dysphagia, worsening } \\
\text { muscle fatigability, dyspnea, MG crisis }\end{array}$ & $\begin{array}{l}\text { Dry mouth, dry eyes and joint pain for } 5 \text { years; } \\
\text { FL (-); parotid ECT (+) }\end{array}$ & $\begin{array}{l}\text { ESR elevated; } \gamma \text {-globulin } \\
\text { elevated; ANA, anti-SSA, } \\
\text { anti-SSB (-) }\end{array}$ & $\begin{array}{l}\text { Cholinesterase inhibitor; } \\
\text { tracheal intubation and } \\
\text { ventilator assisted breathing }\end{array}$ & Die \\
\hline $\begin{array}{l}\text { 2008, China } \\
\text { (17) }\end{array}$ & $F / 41$ & $\begin{array}{l}\text { Muscle fatigability and mild diplopia for } 10 \\
\text { months; dysphagia for } 3 \text { months; anti-AcR(+); } \\
\text { fatigue test(+); RNS(-) }\end{array}$ & $\begin{array}{l}\text { Dry eyes and hair loss for } 3 \text { months; Schirmer } \\
(+) ; \mathrm{FL}(+) \text {; parotid ECT (+) }\end{array}$ & $\begin{array}{l}\text { IgG/A/M elevated; RF (+); } \\
\text { ANA, anti-SSA (+) }\end{array}$ & $\begin{array}{l}\text { Thymectomy(thymic } \\
\text { hyperplasia); steroid }+ \\
\text { pyridostigmine bromide }\end{array}$ & Improved \\
\hline $\begin{array}{l}\text { 2009, China } \\
\text { (18) }\end{array}$ & $\mathrm{F} / 78$ & $\begin{array}{l}\text { Fatigable ptosis, diplopia and dysphagia for } 7 \\
\text { years; anti-AcR(+); fatigue test(+); RNS(+); } \\
\text { treatment: pred } 60 \mathrm{mg} \text { qd } \rightarrow 15 \mathrm{mg} \text { qd and } \\
\text { pyridostigmine bromide; improved }\end{array}$ & $\begin{array}{l}\text { Dry mouth, dry eyes, joint pain; swelling of } \\
\text { parotid glands and low grade fever for } 1 \text { year; } \\
\text { Schirmer (+); salivary flow rate } 0.05 \mathrm{ml} / \mathrm{min}\end{array}$ & $\begin{array}{l}\text { RF (+); ANA, anti-SSA, } \\
\text { anti-SSB (+) }\end{array}$ & $\begin{array}{l}\text { Pred } 15 \mathrm{mg} \text { qd; } \\
\text { pyridostigmine bromide }\end{array}$ & Improved \\
\hline $\begin{array}{l}\text { 2013, China } \\
\text { (19) }\end{array}$ & $M / 63$ & $\begin{array}{l}\text { Productive cough, fatigability and ptosis for } 3 \\
\text { months; anti-AcR(+); RNS(+); chest CT: } \\
\text { thymoma }\end{array}$ & $\begin{array}{l}\text { Dry eyes for } 1 \text { year; Schirmer (+); parotid ECT } \\
(+)\end{array}$ & ANA $(+)$ & $\begin{array}{l}\text { Thymectomy(type-A } \\
\text { thymoma) }\end{array}$ & Improved \\
\hline $\begin{array}{l}\text { 2013, China } \\
\text { (20) }\end{array}$ & $F / 46$ & $\begin{array}{l}\text { Ptosis and mild diplopia for } 2 \text { months; } \\
\text { neostigmine test(+); anti-AcR(+); fatigue } \\
\text { test(+); RNS(+) }\end{array}$ & $\begin{array}{l}\text { Dry mouth, dry eyes, oral ulcers and muscle } \\
\text { pain of lower limbs for } 2 \text { years; Schirmer (+); FL } \\
(+) \text {; parotid ECT (+) }\end{array}$ & $\begin{array}{l}\text { ESR } 38 \mathrm{~mm} / \mathrm{h} \text {; RF (+); ANA, } \\
\text { anti-SSA, anti-SSB (+) }\end{array}$ & $\begin{array}{l}\text { Pred } 50 \mathrm{mg} \text { qd; } \\
\text { pyridostigmine bromide }\end{array}$ & Improved \\
\hline
\end{tabular}




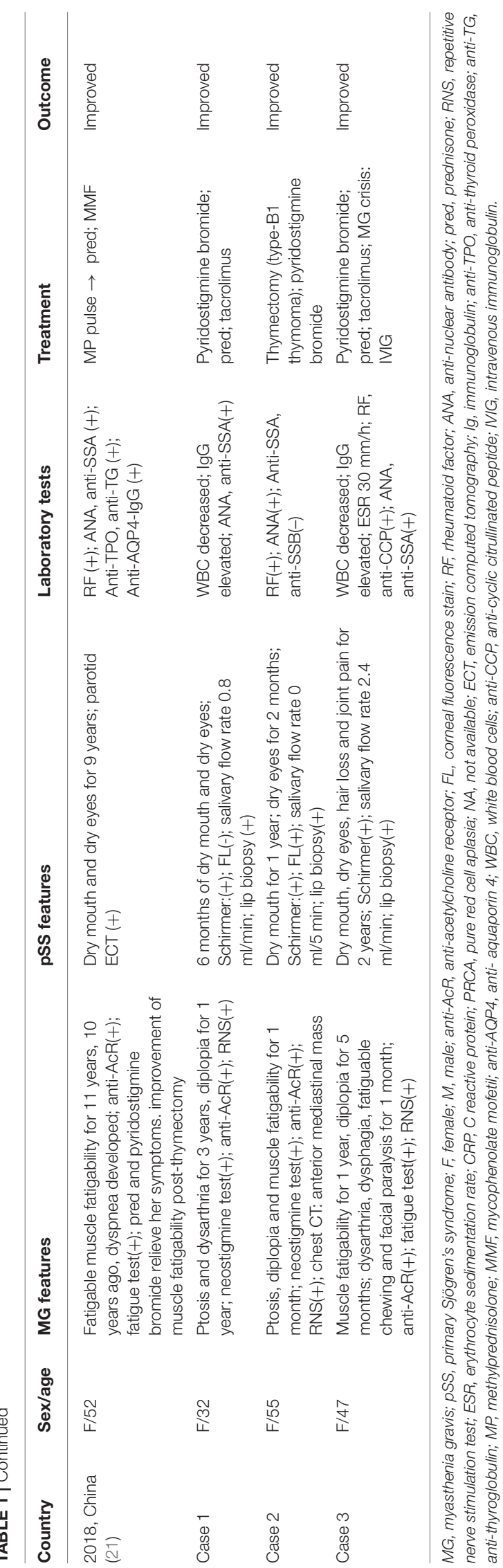

TABLE 2 | Features of patients with MG and pSS.

\begin{tabular}{|c|c|}
\hline Items & Features \\
\hline Median age at onset (years, y) & $48(28 \sim 78)$ y \\
\hline Gender ratio, female:male & $15: 2$ \\
\hline Initial onset of MG & 9/17 (52.9\%) \\
\hline \multicolumn{2}{|l|}{ Median duration } \\
\hline MG to pSS (months, m) & $30 \mathrm{~m}$ (7 m to $20 \mathrm{y})$ \\
\hline pSS to MG (months, m) & $11.5 \mathrm{~m}$ ( $3 \mathrm{~m}$ to $22 \mathrm{~m})$ \\
\hline \multicolumn{2}{|l|}{ MG manifestations } \\
\hline Fatigable ptosis & $11 / 17$ (64.7\%) \\
\hline Bulbar symptoms & 10/17 (58.8\%) \\
\hline Muscle fatigability & $11 / 17$ (64.7\%) \\
\hline Diplopia & $11 / 17(64.7 \%)$ \\
\hline Dyspnea & $4 / 17(23.5 \%)$ \\
\hline Facial paralysis & $1 / 17(5.9 \%)$ \\
\hline Anti-AcR antibody (+) & 12/17 (70.6\%) \\
\hline \multicolumn{2}{|l|}{ pSS manifestations } \\
\hline Sicca symptoms & $17 / 17$ (100\%) \\
\hline Swollen exocrine glands & $4 / 17(23.5 \%)$ \\
\hline Joint pain & 4/17 (23.5\%) \\
\hline Hair loss & $2 / 17(11.8 \%)$ \\
\hline Recurrent oral ulcers & $1 / 17(5.9 \%)$ \\
\hline Raynaud phenomenon & $1 / 17(5.9 \%)$ \\
\hline Fever & $1 / 17(5.9 \%)$ \\
\hline Decreased WBC & $2 / 17(11.8 \%)$ \\
\hline ANA (+) & $12 / 17$ (70.6\%) \\
\hline Anti-SSA (+) & $8 / 17(47.1 \%)$ \\
\hline Anti-SSA and anti-SSB (+) & $3 / 17(17.6 \%)$ \\
\hline Rheumatoid factor (+) & 9/17 (52.9\%) \\
\hline Anti-CCP antibody (+) & $1 / 17(5.9 \%)$ \\
\hline Lip biopsy (+) & $6 / 6(100 \%)$ \\
\hline \multicolumn{2}{|l|}{ Polyautoimmuty } \\
\hline pSS, MG, and $H T$ & $3 / 17(17.6 \%)$ \\
\hline pSS, MG, and thymoma & $3 / 17(17.6 \%)$ \\
\hline pSS, MG, and NMOSD & $1 / 17(5.9 \%)$ \\
\hline pSS, MG, and PRCA & $1 / 17(5.9 \%)$ \\
\hline \multicolumn{2}{|l|}{ Treatment } \\
\hline Cholinesterase inhibitor & 14/17 (82.4\%) \\
\hline Steroids & 9/17 (52.9\%) \\
\hline Immunosuppressants & 4/17 (23.5\%) \\
\hline IVIG & $1 / 17$ (5.9\%) \\
\hline Plasma exchange & $1 / 17$ (5.9\%) \\
\hline Thymectomy & 7/17 (41.2\%) \\
\hline \multicolumn{2}{|l|}{ Outcome } \\
\hline Improved & 16/17 (94.1\%) \\
\hline Died & $1 / 17(5.9 \%)$ \\
\hline
\end{tabular}

MG, myasthenia gravis; pSS, primary Sjögren's syndrome; anti-AcR, anti-acetylcholine receptor; WBC, white blood cells; ANA, anti-nuclear antibody; anti-CCP, anti-cyclic citrullinated peptide; HT, Hashimoto's thyroiditis; NMOSD, neuromyelitis optica spectrum disorder; PRCA, pure red cell aplasia; IVIG, intravenous immunoglobulin.

swollen exocrine glands, four with joint pain, two with slightly decreased WBC). Therefore, no steroids or immunosuppressants were given for treating pSS. Topically symptomatic treatments 
were used as the first-line therapy for oral and ocular dryness based on the European League Against Rheumatism (EULAR) recommendations for the management of pSS (33). The treatment regimens in these coexisting conditions were mainly aimed at MG. Cholinesterase inhibitors were the most common drugs for alleviating the symptoms of MG with affirmative effect (34). For patients with MG who did not respond to an adequate trial of pyridostigmine, corticosteroids could be recommended. Attention should be paid to the precaution that the dose of corticosteroids should be increased gradually to avoid an initial deterioration (35). Immunosuppressive agents were recommended to be used alone or used as corticosteroid-sparing agents, when corticosteroids were contraindicated or refused (35). Among the 17 patients, there were two patients given intravenous methylprednisolone pulse therapy with subsequent oral steroids. And four patients took oral steroids combined with immunosuppressants initially. They all had a good response. IVIG and PLEX could be used in pSS patients with severe systemic involvements, such as severe thrombocytopenia or in MG patients with life-threatening signs, such as respiratory insufficiency or dysphagia $(33,34)$. The effect of IVIG and PLEX treatment was seen in two patients who developed MG crisis with respiratory difficulty (one treated with IVIG, and the other with PLEX). In addition, thymectomy is a special option, not only for the patients with a thymoma, but also for the non-thymomatous anti-AChR antibody positive MG (36). Thymectomy should be considered early in treatment decisions to improve clinical status as the thymus is thought to be a major trigger of autoantibody production (36). We observed that there were seven patients with MG and pSS who received thymectomy, and one patient improved after thymoma resection without any medication.

A single-center retrospective study showed rituximab was effective in patients with MG, supporting the role of B cell depletion in the management of MG (37). It has been reported that rituximab may be a useful treatment for pSS (33). Thus, it is reasonable to speculate that rituximab may be effective for the co-morbidity of MG and pSS. However, no such patient has been treated with rituximab, to date.

Another question is whether hydroxychloroquine (HCQ) can be used in patients with pSS and MG. HCQ is an essential drug for patients with CTDs including SLE and SS, but special caution should be taken when used in MG patients. Although data from the Spanish society of Rheumatology Lupus Registry showed that HCQ protected against polyautoimmunity for patients with SLE (38), Varan et al. reported a case of SLE in which MG developed with the use of HCQ, and regressed with its withdrawal (39). In

\section{REFERENCES}

1. Gilhus NE. Myasthenia gravis. N Engl J Med. (2016) 375:257081. doi: 10.1056/NEJMra1602678

2. Duarte S, Santos E, Martins J, Martins Silva A, Lopes C, Goncalves G, et al. Myasthenia gravis with systemic and neurological polyautoimmunity. J Neurol Sci. (2017) 381:39-40. doi: 10.1016/j.jns.2017.08.010

3. Shiboski CH, Shiboski SC, Seror R, Criswell LA, Labetoulle M, Lietman TM, et al. 2016 American College of Rheumatology/European a series of 17 patients with SLE and MG, Jallouli et al. found that eight patients (47\%) developed MG after initiation of HCQ, but only one patient who received HCQ had an exacerbation of myasthenic symptoms (40). It is worth mentioning that MG has long been recognized as one of the 19 neuropsychiatric manifestations of SLE (41). Therefore, whether it is caused by HCQ or associated with SLE is worth further research. As for the effect of HCQ on the patients with both pSS and MG, there has been no such report to date.

\section{CONCLUSION}

The coexistence of MG with pSS is quite rare according to the reported cases. The onset of MG may occur before or after the diagnosis of pSS. It is of great importance to screen for ANA during the clinical course of $\mathrm{MG}$, and to screen for MG when pSS patients complain of muscle fatigability or fatigable ptosis. Severe morbidity due to pSS is uncommon in patients with both diseases. Thus, controlling the progress of $\mathrm{MG}$ is the critical aspect of treatment. Therapeutic decisions should be made following a multidisciplinary approach. Multicenter prospective studies of larger sample sizes are needed to achieve a better understanding of this co-morbidity.

\section{DATA AVAILABILITY STATEMENT}

The raw data supporting the conclusions of this article will be made available by the authors, without undue reservation.

\section{ETHICS STATEMENT}

The written informed consent was obtained from the participants for the publication of this paper.

\section{AUTHOR CONTRIBUTIONS}

$\mathrm{XL}$ and $\mathrm{YZ}$ collected the patients' data and designed the study. XL wrote the manuscript. YZ, QL, and YD critically revised the manuscript. All authors read and approved the submitted version.

\section{FUNDING}

This work was supported by the National Key R\&D Program of China, Precision Medicine Project-Cohort Study on Nervous System Diseases (Grant no. 2017YFC0907700). 
unrelated, co-occurring autoimmunity? Arthritis Care Res. (2017) 69:106975. doi: 10.1002/acr.23107

6. McCoy SS, Baer AN. Neurological complications of Sjogren's syndrome: diagnosis and management. Curr Treatm Opt Rheumatol. (2017) 3:27588. doi: 10.1007/s40674-017-0076-9

7. Perzynska-Mazan J, Maslinska M, Gasik R. Neurophysiological features of peripheral nervous system involvement and immunological profile of patients with primary Sjogren syndrome. J Rheumatol. (2020) 47:jrheum.181464. doi: 10.3899/jrheum.181464

8. Downes JM, Greenwood BM, Wray SH. Auto-immune aspects of myasthenia gravis. Q J Med. (1966) 35:85-105.

9. Arimori S, Nakata Y, Tada S, Ichikawa Y. Thymic hypertrophy with manifestation of Sjogren's syndrome after remission of myasthenia. Nihon Rinsho. (1973) 31:393-6.

10. Whaley K, Webb J, McAvoy BA, Hughes GR, Lee P, MacSween RN, et al. Sjogren's syndrome. 2. Clinical associations and immunological phenomena. Q J Med. (1973) 42:513-48.

11. Siden A, Lindahl G. Signs of Sjogren's syndrome in a patient with myasthenia gravis. Acta Neurol Scand. (1990) 81:17980. doi: 10.1111/j.1600-0404.1990.tb00958.x

12. Ito $\mathrm{Y}$, Kanda N, Mitsui H, Watanabe T, Kobayashi S, Murayama $\mathrm{S}$, et al. Cutaneous manifestations of Sjogren's syndrome associated with myasthenia gravis. $\mathrm{Br} J$ Dermatol. (1999) 141:362-3. doi: 10.1046/j.1365-2133.1999.03003.x

13. Li YY, Shan H, Liu XZ. A case of Sjogren's syndrome combined with myasthenia gravis. Chinese J Neuroimmunol Neurol. (2003) 10:246. doi: 10.3969/j.issn.1006-2963.2003.04.008

14. Fujiu K, Kanno R, Shio Y, Ohsugi J, Nozawa Y, Gotoh M. Triad of thymoma, myasthenia gravis and pure red cell aplasia combined with Sjogren's syndrome. Jpn J Thorac Cardiovasc Surg. (2004) 52:3458. doi: 10.1007/s11748-004-0068-1

15. Wang ZH, Liu M, Song JH, Cong ZQ. A case of Sjogren's syndrome combined with myasthenia gravis. J Clin Neurol. (2006) 19:424. doi: 10.3969/j.issn.1004-1648.2006.06.030

16. Lin YP, Yu QH, Wu QY. A case of myasthenia gravis presenting with initial symptoms of dry mouth and dry eyes. Chinese J Misdiagn. (2006) 6:18245. doi: 10.3969/j.issn.1009-6647.2006.09.208

17. Zhang J, Yuan Q, Zhang YK. A case of myasthenia gravis combined with Sjogren's syndrome. J Sichuan Univ. (2009) 40:324. doi: 10.3969/j.issn.1672-173X.2009.02.049

18. Wang T. A case of Sjogren's syndrome combined with myasthenia gravis. Chinese J Allergy Clin Immunol. (2009) 3:152-3. doi: 10.3969/j.issn.1673-8705.2009.02.016

19. Tsai Y, Lin Y, Chen C, Tzao C. Thymoma associated with myasthenia gravis and Sjogren syndrome. West Indian Med J. (2013) 62:2645. doi: 10.7727/wimj.2012.118

20. Zhu CM, Li M, Nie DY. A case of Sjogren's syndrome combined with myasthenia gravis. J Apoplexy Nerv Dis. (2013) 30:1129.

21. Feng HR, Zhou HY. A case of neuromyelitis optica spectrum disorder combined with myasthenia gravis, Sjogren's syndrome and Hashimoto's thyroiditis. Chinese J Repar Reconstr Surg. (2018) 17:382-3. doi: 10.7507/1002-1892.201710076

22. Jaretzki A III, Barohn RJ, Ernstoff RM, Kaminski HJ, Keesey JC, Penn AS, et al. Myasthenia gravis: recommendations for clinical research standards. Task force of the Medical Scientific Advisory Board of the Myasthenia Gravis Foundation of America. Neurology. (2000) 55:16-23. doi: 10.1212/wnl.55.1.16

23. Gilhus NE, Verschuuren JJ. Myasthenia gravis: subgroup classification and therapeutic strategies. Lancet Neurol. (2015) 14:1023-36. doi: 10.1016/S1474-4422(15)00145-3

24. Delalande S, De Seze J, Ferriby D, Vermersch P. Neurological manifestations in Sjogren syndrome. Rev Med Interne. (2010) 31:S8-15. doi: 10.1016/j.revmed.2010.03.006

25. Evoli A, Caliandro P, Iorio R, Alboini PE, Damato V, LaTorre G, et al. Polyautoimmunity in patients with myasthenia gravis: a single-center experience. Autoimmunity. (2015) 48:412-7. doi: 10.3109/08916934.2015.1031890

26. Garibaldi M, Fionda L, Vanoli F, Leonardi L, Loreti S, Bucci E, et al. Muscle involvement in myasthenia gravis: expanding the clinical spectrum of myasthenia-myositis association from a large cohort of patients. Autoimmun Rev. (2020) 19:102498. doi: 10.1016/j.autrev.2020.102498

27. Uchio N, Taira K, Ikenaga C, Kadoya M, Unuma A, Yoshida K, et al. Inflammatory myopathy with myasthenia gravis: thymoma association and polymyositis pathology. Neurol Neuroimmunol Neuroinflamm. (2019) 6:e535. doi: 10.1212/NXI.0000000000000535

28. Rojas-Villarraga A, Amaya-Amaya J, Rodriguez-Rodriguez A, Mantilla RD, Anaya JM. Introducing polyautoimmunity: secondary autoimmune diseases no longer exist. Autoimmune Dis. (2012) 2012:254319. doi: 10.1155/2012/254319

29. Xu D, Zhao S, Li Q, Wang YH, Zhao JL, Li MT, et al. Characteristics of Chinese patients with primary Sjogren's syndrome: preliminary report of a multi-centre registration study. Lupus. (2020) 29:45-51. doi: 10.1177/0961203319889666

30. Anaya JM, Restrepo-Jimenez P, Rodriguez Y, Rodriguez-Jimenez M, AcostaAmpudia Y, Monsalve DM, et al. Sjogren's syndrome and autoimmune thyroid disease: two sides of the same coin. Clin Rev Allergy Immunol. (2019) 56:36274. doi: 10.1007/s12016-018-8709-9

31. Lazarus MN, Isenberg DA. Development of additional autoimmune diseases in a population of patients with primary Sjogren's syndrome. Ann Rheum Dis. (2005) 64:1062-4. doi: 10.1136/ard.2004.029066

32. Berrih-Aknin S. Myasthenia gravis: paradox versus paradigm in autoimmunity. J Autoimmun. (2014) 52:1-28. doi: 10.1016/j.jaut.2014.05.001

33. Ramos-Casals M, Brito-Zeron P, Bombardieri S, Bootsma H, De Vita S, Dorner T, et al. EULAR recommendations for the management of Sjogren's syndrome with topical and systemic therapies. Ann Rheum Dis. (2020) 79:318. doi: 10.1136/annrheumdis-2019-216114

34. Sanders DB, Wolfe GI, Benatar M, Evoli A, Gilhus NE, Illa $\mathrm{I}$, et al. International consensus guidance for management of myasthenia gravis: executive summary. Neurology. (2016) 87:419-25. doi: 10.1212/WNL.0000000000002790

35. Sanders DB, Wolfe GI, Narayanaswami P, Guidance MTFoMT. Developing treatment guidelines for myasthenia gravis. Ann N Y Acad Sci. (2018) 1412:95101. doi: 10.1111/nyas. 13537

36. Wolfe GI, Kaminski HJ, Aban IB, Minisman G, Kuo HC, Marx A, et al. Randomized trial of thymectomy in myasthenia gravis. N Engl J Med. (2016) 375:511-22. doi: 10.1056/NEJMoa1602489

37. Litchman T, Roy B, Kumar A, Sharma A, Njike V, Nowak RJ. Differential response to rituximab in anti-AChR and anti-MuSK positive myasthenia gravis patients: a single-center retrospective study. J Neurol Sci. (2020) 411:116690. doi: 10.1016/j.jns.2020.116690

38. Mena-Vazquez N, Fernandez-Nebro A, Pego-Reigosa JM, Galindo M, Melissa-Anzola A, Uriarte-Isacelay E, et al. Hydroxychloroquine is associated with a lower risk of polyautoimmunity: data from the RELESSER Registry. Rheumatology (Oxford). (2020) 59:2043-51. doi: 10.1093/rheumatology/kez562

39. Varan O, Kucuk H, Tufan A. Myasthenia gravis due to hydroxychloroquine. Reumatismo. (2015) 67:849. doi: 10.4081/reumatismo.2015.849

40. Jallouli M, Saadoun D, Eymard B, Leroux G, Haroche J, Le Thi Huong D, et al. The association of systemic lupus erythematosus and myasthenia gravis: a series of 17 cases, with a special focus on hydroxychloroquine use and a review of the literature. J Neurol. (2012) 259:1290-7. doi: 10.1007/s00415-0116335-z

41. The American College of Rheumatology nomenclature and case definitions for neuropsychiatric lupus syndromes. Arthritis Rheum. (1999) 42:599608. doi: 10.1002/1529-0131(199904)42:4<599::AID-ANR2>3.0.CO;2-F

Conflict of Interest: The authors declare that the research was conducted in the absence of any commercial or financial relationships that could be construed as a potential conflict of interest.

Copyright (c) $2020 \mathrm{Li}$, Zhao, Liao and Da. This is an open-access article distributed under the terms of the Creative Commons Attribution License (CC BY). The use, distribution or reproduction in other forums is permitted, provided the original author(s) and the copyright owner(s) are credited and that the original publication in this journal is cited, in accordance with accepted academic practice. No use, distribution or reproduction is permitted which does not comply with these terms. 